\title{
Die roeping van die kerk ten opsigte van die politieke situasie in Suid-Afrika vandag
}

D J C van Wyk

\section{VERKENNING VAN DIE PROBLEEM}

Deur al die eeue van die kerk se bestaan op die aarde het Bybelse teoloë toegegee dat die kerk en indiwiduele Christene 'n verantwoordelikheid het vir die kwaliteit van die sosiale, ekonomiese en politieke orde. En net so konstant was daar verskil oor wat hierdie verantwoordelikheid behels en hoe dit tot uitdrukking moet kom.

Die resente skenkings van die Wêreldraad van Kerke aan terroristebewegings het op dramatiese wyse die gevare gedemonstreer wat verbonde is aan die kerk en Christene se worsteling om die eise van hul geloof relevant te maak in 'n wêreld waarin armoede, onreg, gebrek aan vryheid, wanorde, onderdrukking en die leuen op een of ander wyse kenmerkend gebly het van alle sosiale en politieke sisteme, demokraties en totalitêr.

Dit is redelik eenvoudig om te konstateer dat die kerk ' $n$ plig en roeping het om te soek na groter geregtigheid, vryheid en sekerheid in hierdie wêreld. Die gevaar is egter dat ons dit bely net wanneer dit ons pas. Dit blyk telkens dat mense vrede en genoeë het met die kerk se politieke spreke en getuienis solank daardie spreke inpas in die raamwerk van hul eie politieke beskouings. Sodra dit nie meer so is nie, word geëis dat die kerk hom moet bepaal by die Woord en geloofsake.

In die heersende klimaat vandag in Suid-Afrika verlekker baie mense hulle in uitsprake "dat die Afrikaanse kerke in besluite van vergaderings en in afvaardigings by die owerheid veel sterker moet getuig vir medeseggenskap in gesamentlike belange, oorwinning oor rasse-diskriminasie en bereidheid tot ' $n$ sinvolle politieke kompromie van 'n nuwe staatkundige en maatskaplike bedeling op die grondslag van erkenning van menseregte op alle samelewingsvlakke" en ook "dat die Afrikaanse kerke se leidende, aktiewe rol in verantwoordelike standpuntstelling oor vernuwende geregtigheid, vryheid en waarheid, baie meer in die Suid-Afrikaanse politiek gesien moet word!"1)

Dit is nie moeilik om die krag van Bybelse gesag by 'n uitspraak soos hierdie te kry nie. Terselfdertyd weerspieël dit natuurlik die bekende terminologie en formulering wat geliefd is in die heersende verligte Afrikanerpolitiek. Binne hierdie omgrensing is die kerk se 
politieke bemoeienis vir baie 'n heilige dwang. Daarbuite is dit taboe.

Die omgekeerde gebeur net so konsekwent. Solank die kerk deur sy mondstukke ' $n$ toon aanslaan wat as tradisioneel behoudend ten opsigte van rasseverhoudings en afsonderlike ontwikkeling beskryf kan word, heers daar groot instemming. Bewaar die kerk of enige van sy mondstukke egter wat dit waag om die aanvaarde weë te bevraagteken, al is dit net deur te waarsku teen krenkende optrede teen Swartmense of deur te pleit vir groter billikheid en Christelikheid.

Vanuit hierdie verwarring sal dit vir baie mense 'n uitkoms wees as die kerk hom liewer wil onttrek en hom wil bepaal by geestelike sake. Vir baie vroom en opregte Christene is dit pynlik as sy kerk in politieke vaarwaters beland. Intussen weet die kerk goed genoeg dat hy hom nooit aan hierdie opdrag kan onttrek nie. Dit blyk met die kerk soos dit met Elia, Jeremia, Esegiël, Jona, Paulus of soveel ander was: hy sal so graag as wat hy leef terwille van groter gemak en gerief onder hierdie opdrag wil uit. Maar hy word elke keer daarheen teruggevoer.

Ons kan verwag dat in die jare wat voor ons lê, gemoedere en hartstogte in Suid-Afrika en in ons eie volk en kerk miskien selfs hegtiger as ooit tevore ontroer gaan word. Daarin gaan die vraag al brandender word: bly die kerk werklik kerk? Is dit nog die stem van die kerk wat in die politiek gehoor word, of is dit dalk die stem van die politiek in die kerk waarmee ons ons mense sal probeer voed? ${ }^{2)}$

Die gesprek oor hierdie saak kan vandag verloop teen die agtergrond van 'n paar duidelike voorbeelde uit die ver en naby verlede waar dit baie akuut was: die $19^{\text {de }}$ eeuse koppeling tussen kerk en sending aan die een kant en Westerse kolonialisme en imperialisme aan die ander kant; die Afrikaanse kerke se steun aan die beleid van afsonderlike ontwikkeling in die vyftiger en sestigerjare van hierdie eeu; die Wêreldraad van Kerke se identifikasie met die Derde Wêreld.

As daar gewerk wil word aan 'n ideaal om 'n vorm van konsensus tussen kerke en Christene in Suid-Afrika te bewerk, soos by geleentheid deur dr Willem de Klerk bepleit is, sal die verskille vooraf eerlik onder oë gesien moet word. ${ }^{3)}$

\section{VIR ADVIES NA CALVYN}

Wyle prof Karl Barth het by geleentheid van 'n Hervormingsfees gesê Calvyn het vir ons 'n egte voorbeeld van 'n teologiese lewenstyl nagelaat: hy was 'n leser en uitlegger van die Heilige Skrif wat in die Skrif nie sy eie gedagtes teruggevind het nie, maar God se gedagtes gesoek en gevind het. ${ }^{4)}$ 
Juis daarom bly Calvyn se riglyne vanuit die Bybel oor die owerheid en die wette waardeur die owerheid regeer, vir ons in hierdie saak van die grootste belang."

Calvyn sê die burgerlike owerheid en die Ryk van Christus verskil sterk van mekaar en moet daarom van mekaar onderskei word. Dit beteken egter nie dat hulle teen mekaar stry nie. Soos liggaam en siel van mekaar onderskei word, moet hierdie twee dinge ook van mekaar onderskei word. Nogtans is die nut van die owerheid geweldig groot - net so onmisbaar as brood, son en water.

Calvyn skryf oor die owerheid onder drie gesigspunte:

- die owerheid, wat die wette beskerm en maak;

- die wette self waarvolgens regeer word;

- die volk, wat deur die wette geregeer word en die owerheid gehoorsaam.

Dus:

- Is die owerheid 'n wettige, deur God gewilde instelling waarop sy welbehae rus? Wat is die taak van die owerheid en hoe groot is sy mag?

- Deur welke wette behoort 'n Christelike staat geregeer te word?

- Watter nut het die volk uit die wette? En hoedanige gehoorsaamheid is die volk aan die staat verskuldig?

Ten opsigte van die eerste sê Calvyn dat die owerheid wettig en heilig voor God is en onder die mense van die mees eervolle instellings (1 Tim 2:2). Die owerheid wat van hierdie hoë en heilige roeping van God bewus is, moet vir die mense 'n beeld van God se voorsienigheid, bewaking, goedheid, welwillendheid en regverdigheid voor oë stel. Die owerheid mag nie so vermetel wees om 'n onregverdige oordeel uit te spreek met dié mond wat bestem is om instrument van die goddelike waarheid te wees nie.

Hoedanig is die amp van die owerheid nou volgens die Woord en waarin is dit geleë? Calvyn antwoord: die owerheid word aangestel tot beskermer en verdediger van die openbare onskuld, sedes, eerbaarheid, vryheid en rus. Die owerheid moet sorg vir die algemene welsyn en vrede van almal. So het Dawid beloof om by sy troonsaanvaarding ' $n$ voorbeeld van hierdie deugde te wees (Ps 101). Die owerheid mag nie instem met enige misdaad nie, maar moet die goddeloses, lasteraars en hoogmoediges verfoei en straf. Konings en ander owerhede moet reg en geregtigheid doen. Reg en billikheid kan slegs met strengheid en die oplegging van strawwe gehandhaaf word.

Geregtigheid is om die onskuldiges in bewaring te neem, te beskerm, te red en te verlos. Reg is om die vermetelheid van die goddeloses te weerstaan, hulle geweld te onderdruk en hulle misdade te straf. 
Vervolgens praat Calvyn dan oor die wette wat die siel en senuwee van elke owerheid vorm en waarsonder geen owerheid kan bestaan nie.

Calvyn onderskei hier vanuit die wet van Moses tussen die sedewet, seremoniële wet en die wet van die regte.

Onder eersgenoemde verstaan Calvyn die gebod van liefde en geloof tot God en die medemens. Die seremoniële wet was 'n vorm van kinderlike onderwysing totdat die volheid van die tyd sou kom. Die wet van die regte was die reëling van billikheid en regverdigheid waardeur die mense onskuldig en gerus onder mekaar kon woon.

Aan alle volke is die vryheid gelaat om dié wette te maak wat tot hul eie nut is. Maar dit moet volgens die reël van die liefde ingerig word sodat dit wel in vorm verskil maar dieselfde beginsel het. Verder moet dit op billikheid gefundeer wees. Daar is geen beswaar teen dat die voorskrifte van die wet terwyl dit gebonde is aan omstandighede, verskillend is nie, solank dit maar op dieselfde doel, naamlik billikheid gerig is. Liefde en billikheid moet dus die doel, reël en grens van alle wette wees. Alle wette wat volgens hierdie reël gemaak, op hierdie doel gerig, en deur hierdie grens afgebaken is, bied geen rede tot afkeuring nie, al verskil hulle van die Joodse wet of van mekaar.

Lande kan, indien hulle nie met gruwelike strawwe teen moord en doodslag optree nie, deur hierdie euwels ten gronde gerig word. Soms kom daar tye wat eis dat strengheid en straf vergroot moet word. Nuwe verordeninge moet nuwe oproer besweer. In tye van oorlog sal alle menslikheid verdwyn as daar nie deur middel van ongewone strawwe skrik ingeboesem word nie.

Derdens: watter nut put die gemeenskap uit die owerheid en sy wetgewing? Daarmee hang ook saam die vraag: hoe groot is die eerbied wat die indiwidu vir die owerheid moet hê? Hoever moet die gehoorsaamheid strek?

Daar is mense wat meen die owerheid is oorbodig. Daarteenoor stel Calvyn Paulus se uitsprake in Romeine 13 dat die owerheid ' $n$ dienaar van God is, ons ten goede. Deur die owerheid word ons beskerm teen misdaad, onreg en boosheid.

Die onderdaan moet teenoor die owerheid so 'n eerbiedige houding as moontlik inslaan. Die owerheid moet eerbiedig word as dienaar en gesant van God.

Die onderdaan se gehoorsaamheid moet met 'n bereidvaardige gemoed bewys word, besluite van die owerheid moet gehoorsaam word, belastings moet betaal word, publieke dienste en laste moet aanvaar word, ook die wat dien tot algemene verdediging. 
Wat moet nou gebeur as die owerheid as dienaar van God sleg word en ontaard en die diens waartoe hy geroep is nie meer vervul nie?

Calvyn antwoord: As ons na die Woord van die Here luister, sal ons hoor dat ons nie alleen onderdanig moet wees aan die vorste wat goed en behoorlik regeer nie, maar ook aan die wat niks meer as net hul plig doen nie, om naamlik die welsyn van die mense te dien. Want hoedanig die owerheid ook al is, hulle heerskappy ontvang hulle alleen van God. Dié wat goed en tot algemene nut regeer, is voorbeelde en bewyse van die Here se weldadigheid. Hulle egter wat onregverdig en heerssugtig regeer, is deur God verwek om die ongeregtigheid van die volk te straf. ' $n$ Goddelose koning is 'n teken van die Here se toorn oor ' $n$ land.

Selfs die wreedste en vreeslikste tiran moet gehoorsaam word omdat hy deur God se voorsienigheid en 'n hemelse besluit op die troon geplaas is (Jer 27:17).

Hierdie eerbiedige en vroom gesindheid is ons tot die uiterste toe aan al ons owerhede verskuldig, hoedanig hulle ook al is. Dit beteken dat ons nie die mense self te veel moet ondersoek nie, maar dit voldoende moet ag as hulle deur God op die troon geplaas is. As ons deur 'n hardvogtige tiran gekwel word, moet dit in die eerste plek in ons 'n herinnering wek aan ons sonde wat ongetwyfeld deur sulke gésels van die Here gekasty word.

God self voorsien op sy tyd manne, diensknegte om die misdadige owerheid te straf. Intussen geld dit absoluut: die owerhede, ook die owerhede wat bestaan uit onwaardige mense, het God met majesteit bekragtig en mag deur ons nie verag word nie.

Daar is slegs een uitsondering: die gehoorsaamheid aan die owerheid behoort ons nie af te voer van die gehoorsaamheid aan God nie. Indien die owerheid iets sou beveel wat teen God of sy wil ingaan, moet aan die owerheid ongehoorsaamheid betoon word.

\section{WAT VAN DIE DOODSTRAF EN OORLOG?}

Daar die wet van God alle doodslag verbied, mag die owerheid dan die doodstraf toepas? Calvyn antwoord: doodslag mag nie ongestraf bly nie. Daarom gee die Wetgewer self vir sy dienaars die swaard in die hand. Dit is nie verkeerd om op die bevel van die Here die verdrukkinge van die vromes te wreek nie.

Die owerheid sal hom aan die grootste goddeloosheid skuldig maak as hy die swaard in die skede steek en, om sy hande rein te hou van bloed, die goddelose mense misdadig laat vuortwoed met moord en doodslag. 
Alleen maar: barse en wrede ruheid moet van die regbank verwyder word. Calvyn sê hy wil nie pleit vir norse wreedheid op die regbank nie maar liewer vir sagsinnigheid. Teen beide uiterstes moet die owerheid waak: om nie met te ' $n$ groot strengheid meer te wond as te genees nie; om ook nie in te groot sagsinnigheid en mensliewendheid op te gaan in 'n slap toegeeflikheid wat vele in die verderf sal stort nie. Dit is sleg, sê Calvyn, om onder 'n vors te leef onder wie niks toegelaat is nie. Maar dit is nog slegter om onder ' $n$ vors te leef onder wie alles geoorloof is!

Dit is ook, in die uitoefening van openbare straf, wettig dat die owerheid die wapen opneem en oorlog onderneem. As die owerheid bewaarder en beskermer van die wet is, moet hy ook diegene wat die wet wil omverwerp, straf. Dit geld ook vir die beskerming van die land wat met oorlog bedreig word.

Ook hier mag die owerheid hom egter nie deur toorn, haat en onversoenlike barsheid laat meesleur nie. Hy moet medelyne hê met die algemene menslike natuur en hom slegs deur oorwegings van algemene nut laat lei.

\section{WATTER REGERINGSVORM IS DIE BESTE?}

Calvyn sê dit is nutteloos vir mense om hieroor te redeneer. 'n Belangrike deel van hierdie kwessie is immers geleë in die omstandighede. Dit is God wat in sy voorsienigheid dit so beskik dat verskillende lande deur verskillende regeringsvorms bestuur word. Hy stel konings en ander ampte aan volgens sy (goddelike) goeddunke. Dit hoef nie eers gesê te word vir diegene vir wie die wil van die Here voldoende is nie.

Onder alles deur sê Calvyn, moet die Christen die onderwysing van sy Heer onthou: hy moet ' $n$ mens wees en bly wat smaadheid kan dra, kwaad met goed vergeld en diegene seën wat hom vervloek.

Dit beteken egter nooit dat hy hom nie meer na die owerheid sal wend om hom en sy besittings teen kwaad te beskerm nie. In hierdie lig moet ons Paulus se uitspraak in 1 Korintiërs 6 verstaan. Christene behoort nie deur die geringste oorsake geprikkel te word om na die regbank te hardloop nie. Dit is 'n teken dat die Korintiërs te prikkelbaar van gemoed is en te min bereid is tot lydsaamheid.

\section{DAAR IS KONSENSUS}

In aansluiting by die riglyne deur Calvyn neergelê, kan ons sê dat daar oor 'n paar basiese sake redelike konsensus onder ons sal heers oor die kerk se verantwoordelikheid in die politiek. Ons som dit puntsgewyse op. 
- Die kerk hét hierdie opdrag en verantwoordelikheid. As die staat met sy wette die hele lewe van die mens reël, kan die kerk hom nie afsydig daarvan hou nie. Die politiek moet geheilig word.

- Terwyl hy dit doen, mag die kerk nooit identifiseer met politieke en ideologiese sisteme of hom assosieeer met politieke partye nie. Die kerk moet altyd in staat bly om objektief en krities vir alle magte, partye en ideologieë te sê: so sê die Here! Die kerk moet byvoorbeeld vir beide kapitalisme en kommunisme sê dat hulle beloftes maak wat hulle nie kan vervul nie. Kommunisme beklemtoon ekonomiese regverdigheid en beloof dat vryheid outomaties sal volg na voltrekking van die rewolusie. Kapitalisme beklemtoon vryheid in die ekonomie en beloof dat regverdigheid sal volg as neweproduk van vrye onderneming. Dit het geblyk dat geregtigheid en vryheid nie in een van hierdie stelsels in harmonie kan bestaan sonder dat die een deur die ander vernietig of bedreig word nie.6)

- Die kerk kan slegs breë teologiese en etiese riglyne vanuit die Bybel neerlê. Dit doen hy onder leiding van die Heilige Gees deur geloofsbeslissing. ${ }^{7}$ Dit is nie die kerk se taak nie en hy het buitendien ook nie die kennis om spesifieke advies, oplossings en programme vir die politieke lewe voor te skryf nie. ${ }^{8)}$

- As die kerk die dag politieke kommentaar lewer, moet dit kerklike kommentaar wees; dit moet op 'n wyse gebeur wat die kerk waardig is; dit moet duidelik wees hier praat die kerk; dit moet in gehoorsaamheid aan die Heilige Skrif gebeur; dit moet Bybels-verantwoord wees. Die kerk mag nooit prinsipieel-teologiese spreke laat vaar ten gunste van suiwer politieke spreke nie.

\section{DAAR IS VERSKILLE}

Naas hierdie paar breë, algemene punte waaroor konsensus (en dan ook nie eers altyd en beslis nie tussen alle teoloë en kerke nie) kan bestaan, is daar 'n hele reeks sake waaroor die weë skerp uiteengaan.

- As die kerke in Suid-Afrika oor hierdie saak in gesprek tree, kom spoedig ' $n$ verskil in basiese benadering aan die lig tussen kerke wat die evangelieverkondiging as primêre taak van die kerk sien en kerke vir wie dit primêr om die Christelike handeling gaan. By laasgenoemde leef in een of ander vorm die teologie van die hoop, die teologie van die struktuurkritiek, die politieke teologie, die teologie van die rewolusie. Uit al hierdie teologieë spreek ontevredenheid met die bestaande orde en 'n koorsagtige ywer om deur menslike handeling op politieke en maatskaplike vlak die samelewingstruktuur te verander om op hierdie wyse 
die hoop op die eskatalogiese heil te laat oorgaan in aanskouing. ${ }^{9)}$ Veral in die Suid Afrikaanse Raad van Kerke (SARK) staan hierdie siening in skerp kontras met teologiese aksente in die Afrikaanse kerke.

- Daar leef binne die Afrikaanse kerke die teologiese visie dat dit die evangelie self is wat die verhoudinge binne die maatskappy kersten en dat dit nie op die weg van die kerk lê om die verandering van samelewingstrukture as primêre doel te sien nie. ${ }^{10}$ Vanuit die SARK word dit veroordeel as handige uitvlug wat die Afrikaner versin om sy selfsug te verberg en sy eie bas te red.

Ons wil beweer dat al hierdie bogenoemde teologieë, soos saamgebondel in die SARK, benewens ander besware, ook in stryd is met die sondeleer van die Bybel. Want die Bybel leer nie dat die wêreld 'n beter plek sal word deur struktuurverandering nie, maar alleen as die hart van die mens verander en vernuwe word deur God se vergewende genade. Dit is immers nie die skeiding van taal, kultuur en ras wat die werklike verdelende faktor in die kerk en mensheid as geheel is nie, maar die skeiding wat in die hand gewerk word deur selfregverdiging, liefdeloosheid en magshonger. ${ }^{11)}$

- 'n Ander saak waaroor skerp verskil bestaan, is wat die kerk te doen staan as die owerheid na sy mening demonies word of hom verhinder om God alleen te dien en te aanbid. Die Afrikaanse kerke het nog altyd in voetspoor van Calvyn geglo dat as ' $n$ politieke party of owerheid hom skuldig maak aan magsmisbruik, verkragting van die reg of 'n anti-Christelike ideologie, die kerk dan geroepe is om te getuig vir die heerskappy van Christus op alle terreine van die lewe deur middel van ' $n$ protes, ongehoorsaamheid aan die owerheid of as dit moet, martelaarskap. Die Wêreldraad van Kerke het egter in ons tyd die radikale stap geneem om strydig met die visie van Calvyn, geweld teen die bestaande orde en owerheid daadwerklik te steun. Die verdere vraag is: wanneer is ' $n$ owerheid demonies? Kan enige Suid-Afrikaanse wetgewing werklik rede tot ongehoorsaamheid aan die owerheid wees?

\section{DIE KERK SE TAAK}

As ons vra na die taak van die kerk in die huidige situasie in SuidAfrika, wil ons in die eerste plek dit sê:

- Dat die kerk 'n stem het, is sy kosbaarste besit en om te preek vir die wêreld is sy hoogste roeping. Die kerk moet nougeset toesien dat hierdie besit, reg en vryheid hom nie ontneem word nie. Hy sal moet waak teen die versoeking om in plaas van kerk van die 
Woord, kerk van die daad te word. Die kerk het nog altyd meer bereik deur wat hy sê as deur wat hy doen. Die krag van die kerk is geleë in die Woord wat hy verkondig en nie in die daad wat hy doen nie. ${ }^{21}$

- Daarby moet die kerk baie goed onthou dat die Woord wat hy preek kragteloos word as dit nie begelei en bevestig word deur dade van geregtigheid, dankbaarheid en liefde nie. Daarom moet die kerk hom met prediking en getuienis voor volk en owerheid uitspreek vir groter geregtigheid, billikheid, vryheid en liefde in Suid-Afrika. Laat daar geen twyfel oor bestaan nie. Die kerk moet dit met krag en in duidelike taal doen. Maar juis rondom hierdie uitspraak bestaan vandag soveel verwarring wat spruit uit eensydigheid. Die wyse waarop die afgelope jare soms op ondeurdagte wyse op loop gesit is met die "uitskakeling van diskriminasie", bevorder nie die saak nie; so ook nie die wyse waarop die Afrikaner houe toegedien word "oor die onreg en paternalisme wat hy pleeg nie".

- Ter wille van groter balans moet die kerk, terwyl hy pleit vir groter geregtigheid, vryheid en liefde, bewus wees en bly daarvan dat die Marxisme hierdie selfde taal praat; dat die Marxisme op behendige wyse die emosie en sentiment van die Christen oor al hierdie deugde uitbuit. Die kerk moet ook bly onthou dat hy die oorvereenvoudigde, reglynige antwoorde wat die Marxisme oor probleme soos armoede en onderdrukking het, nie uit die Bybel kan gaan haal nie. Juis as die kerk geloofwaardig wil wees, moet hy ophou om 'n naprater van verwarrende Marxistiese terminologie en oplossings te wees. As die kerk in SuidAfrika sy roeping wil vervul, moet hy leer om opnuut uit die Bybel op vars, oorspronklike, nuwe wyse te praat oor die vreemde geregtigheid van Christus.

- Daarby kom dat daar ook ander eise is wat die kerk aan die samelewing in Suid-Afrika mag stel: byvoorbeeld dat daar orde sal heers. Die kerk het immers alle belang daarby om 'n ordelike, rustige en stil lewe te kan lei. Chaos en anargie dien nie die kerk nie, en ook nie die welsyn van die mense nie. En as 'n deel van hierdie kerk, op sowel Bybelse gronde asook op grond van Calvyn se uitspraak dat besondere omstandighede besondere wette regverdig, juis in diens van orde, hom uitspreek ten gunste van ' $n$ breë beleid van skeiding omdat hy daarin 'n Christelike oplossing vir 'n probleem sien, mag hy seker vra dat daarvoor ook begrip sal bestaan. Kan van Swart Christene en kerke ook' $n$ keer geëis word om hulleself rekenskap te gee van die WELDAAD wat die owerheid as chaosbedwingende mag, ook die owerheid in Suid-Afrika met al sy foute en gebreke vir hulle inhou? 
- Daar is verdere vrae wat ter wille van groter balans noodwendig gevra moet word. Is die oordrewe simpatie wat vandag aan die armes en onderdruktes betoon word, werklik so Bybels gefundeer? Het Calvyn nie baie beter en omvattender na die Skrif geluister nie toe hy gesê het God staan nie net aan die kant van die armes en onderdruktes nie, maar doen ook reg aan die wat, terwyl hulle goed doen, belaster word? Die billike en gebalanseerde oordeel oor die Westerse en Suid-Afrikaanse sogenaamde paternalisme moet nog uitgespreek word. Wat meer is: moet die kerk werklik 'n ideologiese humanisme bevorder of gaan dit om 'n Christelike humaniteit? Word daar redelike eise aan die owerheid in Suid-Afrika gestel? Is dit te midde van die hewige bombardement van kritiek, veroordeling en venyn nog moontlik om 'n objektiewe, gebalanseerde oordeel te vorm oor die mate waarin Suid-Afrikaanse wetgewing aan die norme van billikheid en liefde voldoen?

- Die kerk moet sekerlik vir owerheid en volk sê dat die lewende God nie as vroom volksvader deur elkeen van ons misbruik mag word nie. Maar die profetiese roeping van die kerk teenoor die owerheid beteken nie dat die kerk byvoorbaat as opposisie en in 'n veroordelende houding teen die staat te staan moet kom nie. Die kerk moet ook vir die owerheid bid. Dit is skandelik dat oor die nalating hiervan soms in ons kerke gekla word. Die kerk moet ook voor die owerheid getuig hoe hy volgens die Woord sy taak moet vervul. Die kerk in Suid-Afrika het 'n ontsaglike verantwoordelike taak om die owerheid te help om te onderskei tussen wat legitieme griewe en eise van Swartmense is en wat suiwer Marxisties-geïnspireerde propaganda is. Die kerk moet liewer probeer om weg te kom van die uiters verwarrende en misbruikte term diskriminasie en aan die owerheid voorligting gee, nie op lukraak wyse nie, maar na grondige studie, oor watter wette aan die eise van billikheid en liefde voldoen en watter nie.

- Die Afrikaner en sy kerk moet eerlik en krities wees met homself. Die Afrikaanse kerke het deur die jare 'n hegte solidariteit met die Afrikanervolk gehandhaaf. Gun ons aan die Swart kerke dieselfde solidariteit met die Swart volke in Suid-Afrika? Die beskuldiging dat die Afrikaner in hierdie opsig inkonsekwent en skynheilig is deur oorhaastig die Swart kerke se uitinge van solidariteit met hul mense, ook waar dit baie eg is, as goedkoop politiekery te veroordeel, lyk nie altyd ongegrond nie. Ook nie die verwyt dat die Afrikaanse kerke hulle in die jare wat verby is te sterk met die beleid van afsonderlike ontwikkeling vereenselwig het nie. 
Maar hierdie kritiese ingesteldheid moet na alle kante toe sny. Dit word te eensydig net aan die Afrikaanse kerke opgedring. Daar moet ook deur die kerk gewys word op die totaal onrealistiese verwagtinge wat in die Derde Wêreld en by Swartes in Suid-Afrika gewek word; verwagtinge wat dikwels alle beskikbare bronne en mensemateriaal ver oorskry.

- 'n Laaste opmerking. Die mens wat deur die geloof medeweter geword het van die orde van God sal self nooit 'n ordelose wees nie, of ' $n$ agitator of iemand wat heimlik die bestaande orde ondergrawe nie. Dit is geen goeie getuienis as die owerheid teen GELOWIGES moet optree wat die landswette nie gehoorsaam of die veiligheid van ' $n$ land in gevaar stel nie.

Die kerk moet met nuwe geloofserns die eer van God verkondig en sê dat Jesus die Here is. Die kerk moet vir die owerheid aanhou sê: ryk en arm, Swart en Wit wil hom tot jou wend om teen geweld, intimidasie, onreg, onderdrukking en valse beskuldiging beskerm te word. En die kerk moet vir Wit en Swart sê: leer saam om ter wille van Christus smaad te verdra.

En onthou Paulus se reaksie op die partyskappe van die Korintiërs: julle behoort aan Christus en Christus aan God. 'n Kerk wat geheel in diens van Christus staan, het nie tyd en begeerte om flirtasies met ideologieë en politieke sisteme aan te gaan nie; of dit die Nieu-Marxisme, Kapitalisme, Sosialisme, Rassisme of watter ander sisteem ook al mag wees. En omgekeerd: 'n Kerk wat hierdie flirtasies kan bekostig, het daarmee klaar sy verloëning van die enige Heer voltrek.

\section{Verwysings}

1 Willem de Klerk, Oggendblad, 14 Augustus 1980.

2 F J van Zyl, Die stem van die kerk in die wêreld, Hervormde Teologiese Studies, Jaargang 32, Afl 1 en 2, bl 96.

3 Willem de Klerk, Die Transvaler, 14 Julie 1980.

4 A D Pont, Die Calvinisme vandag, Hervormde Teologiese Studies, Jaargang 35, Afl 1 en 2 , bl 1.

5 Joh Calvyn, Institutie, vertaling A Sizoo.

6 Ernest W Lefewer, Amsterdam to Nairobi, The World Council of Churches and the Third World, Ethics and Public Policy Centre, Georgetown University, Washington, D C, 1979.

7 C J Mans, Die owerheid in die Nuwe Testament en by die Reformatore, Hervormde Teologiese Studies, Jaargang 18, Afl 3, bl 104.

8 C H Rautenbach, Die Hervormer, Oktober 1980.

9 F J van $Z y l$, aw, bl 94.

10 J P Oberholzer, Die kerk van die staatkundig-kulturele vlak van die volkslewe, Hervormde Teologiese Studies, Jaargang 25, Afl 3 en 4, bl 222.

11 J P Oberholzer, Is there a future for the World Council of Churches?, Hervormde Teologiese Studies, Jaargang 23, Afl 1 en 2, bl 76.

12 F J van Zyl, aw, bl 95. 